To the Editor of THE LANCET.

Sir,-I beg leave to state that, fully approving of the plan for raising $£ 500$, to constitute the "Reform Fund," I shall willingly hold myself responsible for the sum of $10 s$, in the event of there being the required number of promises to secure the amount required, if guaranteed by legally-qualified practitioners.

I am, Sir, yours respectfully,

Jewry-street, March, 1819. HENRY IIADLOW, M.R.C.S., L.S.A.

To the Editor of THE LANicet.

Sir,-.The suggestion of "Quod bcne Vertat" is good, but suggestions, unless followed up, are valueless. Let, then, our motto be "Action;" and as I have no doubt the necessary amount will be raised, I herewith inclose my subscription to the "Medical Reform Fund."

Blackburn, Feb. 1849.

I am, Sir, your obedient servant JoHN CURrIE, I.R.C.S.E.

\section{THE OPERATION FOR STRANGULATED HERNIA.}

\section{To the Editor of THE LANCET.}

Srr,-I beg to assure Mr. Gay, that if, in his first letter to you, he had acquitted me, with the same distinctness of expression as he has done in his last, of being in any way concerned in the preparation of the review of his book, which he has complained of as being unfair, I should not have troubled either you or your readers with my former communication.

What I had reason to be dissatisfied with was, not Mr. Gay's apology, but that he had managed it so, that no one of your readers, without a knowledge of the previous communication which had taken place between Mr. Gay and myself, could, by any possibility, understand to whom it referred; while he so expressed himself in a subsequent part of his letter as to lead your readers to believe, that he still suspected, "I think from the context, a surgeon of the London Hospital."

That it was not $I$ who first put this construction upon these passages in his letter, or improperly applied the latter passage to myself, I would inform $M r$. Gay that my attention was first called to it, as referring to me, by ove of your most intelligent and generally respected readers, not knowing at the time of his doing so, to whom Mr. Gay's apology was tendered. It was obvious that other readers might do the same thing, and attribute to me the anthorship or sanction of a review which Mr. Gay has declared to be unfair. Should such readers agree with Mr. Gas in considering the review unfair, I necessarily must have suffered in their estimation as having been guilty of unfairness. I am sorry Mr. Gay has not seen that this would have been the effect of his first letter, if left unexplained. To obviate this, was the intention of $\mathrm{my}$ former communication.

In that communication I hope there is no expression of anger or bitterness of feeling, such as Mr. Gay attributes to me, for none such exists in my mird. I have already acceted his apo$\operatorname{logy}$, and retain no angry feeling upon its subject; believing this to be the spirit with which gentlemen do accept apologies.

Mr. Gay, however, in his ardour of defener, seems, by his comments upon my letter, to forget that the passages in it relating to the operation were written chiefly with a view to show that I had no disposition to depreciate the prinsiple which it involved. These passages were to the effect, that for many years, and long before Mr. Gay entertained the idea, I had adrocated and practised a proceeding precisely similar in principle, and somewhat similar in performance, but with adrantages in certain forms of stricture, on hernial contents, which I thought Mr. Gay's operation did not possess, and I concluded with the observation, that "I had no wish to stultify myself by depreciating an operation, the main principle of which I approved." I do not expect that Mr. Gay will acknowledge the advantag $s$ of my proceeding in ariy case, because $\mathrm{I}$ am aware that parents usually prefer their own children, and will palliate or conceal even their faults However this may be, I have no wish to quarrel with a younger member of the same family as my own, and $I$ wish Mr. Gay success in his new undertaking.

$I$ believe that $I$ have not in any place used expressions that will, in the least degree, lead your readers to suspect that $\mathrm{Mr}$. Gay has claimed merit for "more than belongs to him." Hence all the passages in his letter relating to that matter are unnecessary and uncalled for. I quoted sentencts from my paper in the Transactions of the Medico-Chirurgical Society, and in Mr. Gay's book, and placed them in juxtaposition, to show more clearly that the principles ennuciated were the same in both; nor did $I$ think it necessary, in doing so, to guard against the inference alluded to by Mr. Gay, because I had a better opinion of your readers' intelligence than is implied by his complaint.

Mr. Gay is aggrieved that $I$ have made allusion to "inaccura- cies" in bis bonk, and occupies a large portion of his letter in correcting two which I pointed out to him. He might have corrected a third, of a trivial nature, which he has reproduced in his letter. Mr. Gay has thns, I believe, as far as his knowledge of them extends, performed his promise to me, but not upon the "earliest opportunity." I did not draw, nor did I wish your readers to draw, any unfavourable inference from these probably accidental "inaccuracies;" and it appears to me to argue an excessire degree of morbid sensitiveness on Mr. Gay's part to question the propriety of my expressing the exact truth wih respect to my letter to him, in which the word occurs. Did Mr. Gay wish that the profession should believe there were no inaccuracies in his work? If he did not so wish, why does he complain that I first made public allusion to them? I think I might, with more reason, complain that Mr. Gay did not publish my letter to him, at the same time he published those of Mr. Lawrence and Mr. Key, and taken that as the "earliest opportunity" of correcting the inaccuracies therein alluded to. If he had done so, it would have rendered my former letter to you unnecessary, and, I repeat, " removed from Mr. Gay an imputation of practising reserve."

I now, as I have done before, purposely abstain from expressing any opinion concerning the fairness or unfuirness of the review of Mr. Gay's book, and he seemingly labours under a great misapprehension of the passage in my former letter, in which allusion is made to it. If he had intelligently read the whole of the passage, part of which only he quotes and comments on, he would have found that my object was to avoid the inference naturally arising out of his own expression, that I "indignantly disowned" "having anything to do with the article" in the journal. I will endeavour to convey, if possible, my meaning to Mr. Gay, in other words than I then used. I dssowned "having had anything to do with the article," but my indignation was at the suspicion of duplicity raised against ne by Mr. Gay. Mr. Gay, however, was in error, and freely made an apology for his error. I accepted it. In this way, with the suspicion removed which I and others thought attached to me throwgh Mr. Gdy's omission, I hope my correspondence on this subject will cease, leaving no recollection of offence on either side.-I am, Sir, your obedient servant,

Broad-strect-buildings, March, 1819.

JAMES LUKE.

\section{MEDICAL REFORM, AND THE POOR-LAW MEDICAL} OFFICERS.

To the Editor of The Laricet.

SiR,-Will you permit me the favour to say a word in $\mathrm{r}+\mathrm{fer}$ ence to your note appended to $\mathrm{my}$ communication, in the last number of THE LANCET?

In taking the liberty to adrise that the evidence taken before the committee of the House of Commons, of the last session, should be the basis of an Act to reform the medical profession, I was not unmindful of the fact that, although all the gentlemen who expressed opinion and gave evidence agreed in favour of the necessity of a legislative measure, they did not all agree as to the precise conditions and modes of procedure.

Absolute unanimity was not to be expected. But in the course of discussion in the committee, or in the house itself, all the evidence having been considered and weighed, each opinion and each fact would have its due weight and value in the arrangement, and an unexceptionable result might fairly be expected.

Most ardently is it to be desired that some such legislative measures should be effected, which wonld allay and set at rest the present uneasy state of the medical profession, so that we might apply our minds, with undisturbed tranquillity, to the science and the practice of our divine art.

I humbly conceive, therefore, that all branches, and every in dividual member of the profession, should immediately petition for a liberal and comprehensive Bill, which shall reconcile hostile feelings, jarring differences, and fancied special or selfish interests, for the completion of which, those who undertake the task will be entitled to the everlasting gratitude of the profession, and of the country.-I have the honour to remain, Sir, very faithfully yours,

Rcigate, March, $18: 9$. Thomas Martin.

\section{THEORY OF FEVER.}

[NOTE FROM MR. TODD.]

To the Editor of THE LAXICET.

SIR,-DD. Addison has very kirdly directed my attention to an error into which I have inadvertertly fallen, and which I take the first opportunity of rectilying. In my first paper on continued fiver will be found the following quotation: - "Dr. Addison thinks that modifications exist, to a remarkabie extunt, 
in the effects of malaria. For instance, he says, that in a very hot autumn, succeeding to a damp summer, in marshy plact's, the niasma appeared to be copious and intense, and a patient who had been reaping in those districts was brought to Guy's Hospital in a state of typhus, or of severe continued fever."

This quotation, the Doctor says, is a total misapprehension of his meaning, and would imply, that he considered the fever brought from the marshy district to be genuine typhus, or common continued fever; whereas, the case was intended to illustrate the very reverse, and to show, that although it resembled continued fever, or typhus, it was to be regarded a mere modification of marsh, or intermitting, or rather remitting fever; and the proof of this being the case was, that after the patient was placed in a well ventilated apartment, his bowels relieved, and his diet regulated, the remitting character became developed, and the disease was speedily cured by quinine.

It is also necessary that I should state, that Dr. Addison believes that what we call idiopathic fever is of two kinds, and is of two kinds only, all over the world-ihe one of vegetable, the other of animal origin; the former including intermittents, re. mittents, and those apparently continued fevers, in which, from accidental external causes, or from internal local irritations, have their remissions so masked, and the general disturbance so considerable, as to put on the appearance of continued fever, - the latter arising from contagion, and from contagion alone; all other reputed canses being merely such as predispose to the disease. It is also the opinion of Dr. Addison, that in temperate climates, like our own, as well as in the tropies, two poisons not unfrequently co-operate, and thereby modify the symptoms of each oth $\lrcorner$ r.--I am, Sir, your obedient servant,

Evenwood, March, 1849. Georae TodD."

\section{fAlevical \$2ebs.}

Royal College of Surgens.-The following gentlemen having undergone the necessary examinations for the diploma, were admitted members of the college at the meeting of the Court of Examiners on the 2nd inst.:-

Allen, Peter, Smarden, near Cranbrook, Kent.

Cooke, Wrulram, Gainsborough.

GibBs, John George, Baker-street, Portman-square.

Gwyn, Grorge Frederick, Long Stratton, Norfolk.

Hayne, Wrumam Rexrolds, Sussex-terrace, Camden-town. Johnson, Williani Henry, Weymouth, Dorset.

Smrth, JoHN, London.

At the same meeting of the court, Mr. Mark Haurlton passed his examination for naval surgeon. This gentleman had previously been admitted a member of the college, his diploma bearing date June $20 \mathrm{th}, 1842$.

Apothecarigs' Halu.-Names of gentlemen who passed their examination in the science and practice of medicine, and received certificates to practise, on Thursday,

March 1st, 1849.

Crowther, Thomas, St. John's, near Halifax.

Henning, Richard Skinner, East Brent, Somerset.

Izod, Freeman, Esher.

Marshalu, Thomas Harrison, Kingston-upon-Hull.

Prowse, John, Somerset.

Webe, WiLliam, Shrewsbury.

Whitbodri, Frederick, Epsom.

The Cholera is Paris.-Dr. Gardet has published, in L'Union Médicale, the case of a boy, twelve years old, who died with all the symptoms of cholera.

Bedfond General Infirmary.-Paris Thomas Dick, Esq., M.D , has been appointed physician to this Infirmary, in the room of Dr. Witt, resigned.

THE Use of UNFERMENTEd BREad.-This is a subject well deserving attention, for several reasons: 1st, The quality of the bread is superior to that made by any other process; it is much sweeter, and keeps much longer. 2ndly, The process by which it is made (without yeast, with soda and acid) is much shorter, and so simple, that night-work is altogether obviated. And last, though not least, we believe it to be more wholesome, as it is also more economical, than the bread prepared in the usual way. Mr. Elsworthy, of Southampton-row, Russell-square, deserves much credit for the perfection to which he has brought the process. We can speak from personal experience of its excellence.

The Croonian Lectures.-Dr. Conolly delivered the first of these for the present year, at the College of Physicians, on Wednesday, February 28th. It treated of the symptoms charac- terizing the access of insanity, and on the physical alteration of the brain in that disease. The second lecture was delivered on Narch 2nd, and the third on Wednesday last, the 7 th inst. We shall speedily present these lectures to our readers, revised specially for publication, in THE LANCET, by the learned lecturer.

Unyersity College and Hospital.-(From the Times.)The annual meeting of the gorernors, council, and members of this college, was held lately, at the college,-Mr. Warburton, M.P., in the chair. The annual report stated, that during the session of $1847-48,315$ pupils in medicine, 2.32 in the arts, and $30 \mathrm{~s}$ pupils of the junior school, had en tered the college, the fees paid by them amounting, in the whole, to $15,302 l$. 14s. The council hud, during the session, been informed that the existing library and lecture-rooms were not large enough to accommodate the pupils, and they had therefore engaged Mr. Donaldson, the architect, to erect premises in the rear of the college, in the place of the erection destroyed by fire in 1836 . The basement floor was for models of machinery and drawing; and there were also two large rooms, each to accommodate 150 students. The cost of the building, which was nearly finished, would be $7657 \mathrm{l}$. The committee regretted that the funds of the hospital were not in a flourishing condition, they having lately been $3000 l$. in debt. To meet this demand, 1200l. had been raised by subscriptions. A Mr. Kennedy had bequeathed the sum of $500 l$; her Majesty had that morning presented them with $300 l$, out of the estate of the late Mr. Sawyer, of York; and there were several other sums, amounting to $1600 l$., which would enable them to clear the income of the hospital from encumbrance. There were 120 beds in the hospital, and there would soon be increased accommodation. The committee had to express their deep regret at the loss of the Earl of Auckland, their late vice-president, and also for the deaths of Mr. Liston and other gentlemen of note, whose talents were much missed. The expenditure of the college bad exceeded its income by $500 l$, which they had to draw from the funded stock, and though the number of the pupils had greatly decreased, they attributed that to the depressed state of the nation.

["The State of The Nation," forsooth! What arrant nonsense! Does not everybody know that it is the state of destitution caused by the state of intrigue, cabal, and misgovernment in the establishment itself? If there be not be not speedily a radical reform within the walls of the college and hospital, the number of students is likely to decline, until, at last, the number will be reduced to a cipher. If it be the "state of the nation" which has caused the decrease in the number of students at University College, what is it that has produced the increase at King's College, and the various other large medical schools of the metropolis ?]

LrFe Assurance OfFices. - It is gratifying to find that our continued agitation to induce the directors of the above offices to remunerate medical men for their opinions is daily gaining ground. We consider the medical profession bound to support those offices who recognise the principle that the labourer is worthy of his hire; that his opinion is as valuable as the lawyer's. At the anniversary dinner of the Engineers, Masonic, and Universal Mutual Life Assurance Society, last Tuesday, at the Freemasons' 'Tavern, Prof. Ansted truly observed, that the directors depended on the medical man for his opinion; that his time was money; and that the above office had, from the commencement, remunerated the practitioner for his opinion; an example that was being followed by many other offices, in consequence of the exertions of THE LANCET, and the medical press generally-a statement that was warmly applauded to by a highly respectable company.

Benefrcence.-Mrs. Mary Tucker, of Bramford-Speke, in the county of Devon, has bequeathed the following princely donations to medical charities. The Devon and Exeter Hospitals, 1000l.; Barnstaple Infirmary, 600l. ; Exeter Dispensary, 200l.; Windsor Dispensary, 200l.; Hospital for the Cure of Consumption, $100 l$; Society for Incurables, $100 l$. ; and the Sy rian Medical Aid Society, 50l. In addition to the above, this truly excellent lady has bequeathed $12,000 l$. to other charities, principally, if not entirely, selected by Sir R. H. Inglis, Bart., M.P.

“THE FexlowstrIP."- The next examinations for this distinction, will take place at the College of Surgeons, on Monday and Wednesday, the 2nd and 4th of April next. The particulars are given in our advertising columns.

North Wales Hospital for the Trsane.-This institution, situated at Denbigh, is now open for the reception of lunatics.

Mortality of THE Mistrofolis. - Deaths during the week ending March 3rd, 1138, or 31 below the winter average, and a decline on the previous week of 53. Scarlatina, though it has 